\title{
Perkembangan Sosial Islam di Thailand
}

\author{
Mania \\ Universitas Islam Negeri Alauddin, Makassar, 92113, Indonesia \\ *email:mania@gmail.com
}

\begin{abstract}
Abstrak
Thailand merupakan salah satu Negara di wilayah di Asia Tenggara yang mayoritas penduduknya beragama Budha. Tetapi di dalam Thailan terdapat provinsi yang mayoritas penduduknya beragama Islam yaitu di Thailand Selatan. Tepatnya di Pattani dan beberapa provinsi lainnya. Islam masuk di Thailand dengan cara perdagangan oleh orang-orang Arab. Buktinya lukisan kuno yang menggambarkan bangsa Arab di Ayuthaya, sebuah daerah di Thailand dan juga keberhasilan bangsa Arab dalam mendirikan Daulah Islamiyah. Meskipun Islam merupakan agama yang minoritaas di Thailand tetapi Islam mempunyai lembaga yang berpengaruh di Thailand yaitu Patani United Liberation Organization (PULO).
\end{abstract}

Kata Kunci: Islam, sejarah, Thailand

\begin{abstract}
Abstact
Thailand is one of the countries in the region in Southeast Asia where the majority of the population is Buddhist. However, in Thailand, there is a province that is predominantly Muslim, namely in Southern Thailand. Precisely in Pattani and several other provinces. Islam entered Thailand by means of trade by Arabs. The proof is the ancient paintings depicting the Arabs in Ayuthaya, a region in Thailand and also the success of the Arabs in establishing Daulah Islamiyah. Although Islam is a minority religion in Thailand, Islam has an influential institution in Thailand, namely the Patani United Liberation Organization (PULO).
\end{abstract}

Keywords: History, Islam, Thailand

\section{Pendahuluan}

Thailand adalah sebuah Negara di wilayah Asia Tenggara yang berbentuk Monarki Konstitusi (suatu pemerintahan yang didirikan di bawah sistem konstitusional yang mengakui Raja, Ratu, atau Kaisar sebagai kepala negara). Islam masuk di Thailand diperkirakan sekitar abad ke-10 atau ke-11 dibawa oleh pedagang Arab dan India. Islam pernah berkuasa di wilayah Pattani sejak berdirinya Kerajaan Islam Patani abad ke-14. Namun, sejak berada dalam kekuasaan Kerajaan Siam, hingga sekarang umat Islam menjadi minoritas dan terdiskriminasi oleh pemerintahan Thailand.

Muslim Thailand sebagian besar tersebar di empat propinsi bagian selatan, yaitu Pattani, Yala, Narathiwat dan Satun. Mereka kerap memperoleh problem dan kekerasan oleh pemerintah. Hingga saat ini Muslim Thailand terus berjuang untuk memperoleh hak-haknya. 
Ada beberapa pendapat tentang masuknya Islam ke Asia Tenggara. Yang pertama pendapat orang-orang Eropa dan yang kedua pendapat sejarawan arab dan muslim. Pendapat sebagaian besar sejarawan Eropa secara mutlak berpegang pada apa yang disebutkan oleh pengembara Italia Marcopolo bahwa masuknya Islam ke Asia Tenggara adalah pada abad ke tiga belas masehi di sebelah utara pulau Sumatera dan mereka membatasi pendapat mereka pada perjalanan Marcopolo ini ke daerah tersebut pada $1292 \mathrm{M}$.

Adapun beberapa pendapat sejarawan Arab dan muslim tentang sejarah Asia Tenggara sebagai berikut:

Muhammad Dhiya'Syahab dan abdullah bin Nuh dari indonesia mengatakan:

"Banyak buku-buku sejarah dari barat dan orang-orang yang mengikutinya yang mengira bahwa Islam masuk ke Indonesia pada abad ke tiga belas Masehi. Tetapi saya berkeyakinan bahwa masuknya Islam ke Asia Tenggara jauh sebelum masa yang diduga oleh orang-orang asing itu dan para pengikut mereka”.

Mufti kesultanan Johor, Malaysia syarif Alwi bin Thohir Al Haddad mengatakan:

"Pendapat-pendapat para sejarawan tentang masuknya Islam ke Asia Tenggara adalah tidak tepat. Terutama pendapat sejarawan Eropa yang menetapkan utama pendapat sejarawan Eropa yang menetapkan masuknya Islam ke Jawa pada tahun 800$1300 \mathrm{H}$, di sumatera dan malaysia pada abad ke 7 Hijriah. Kenyataan yang benar bertentangan dengan apa yang mereka katakan. Karena sesungguhnya Islam telah mempunyai raja-raja di Sumatera pada abad ke enam bahkan ke lima Hijriah".

Dr. Muhammad Zaitun mengatakan :

"Walaupun para sejarawan menyebutkan masuknya islam ke Malaysia pada abad ke enam Hijriah (abad kedua belas Masehi), pendapat yang lebih kuat adalah islam telah masuk kesana jauh sbelum itu. Mungkin tahun yang telah disebutkan oleh mereka hanya menjelaskan catatan-catatan sejarah (prasasti) yang sampai kepaanya sesudah pemerintah wilayah-wilayah tersebut memeluk agama islam dan terbentuk kesulthanankeshultanan Islam di daerah tersebut. Di Malaysia wilayah kedah adalah wilayah yang paling cepat memeluk Islam”.

Berkaitan dengan hal tersebut, artikel ini bermaksud mengkaji tentang kondisi georafis penduduk Thailand, sejarah Masuknya Islam di Thailand, kehidupan keberagamaannya, dan perkembangan muslim Thailand (dalam berbagai aspek).

\section{Pembahasan}

\section{Sekilas Tentang Negara Thailand}

Asal mula Thailand secara tradisional dikaitkan dengan sebuah kerajaan yang berumur pendek, yaitu kerajaan Sukhotai yang didirikan pada tahun 1238. Kerajaan ini kemudian diteruskan kerajaan Ayutthaya yang didirikan pada pertengahan abad ke-14 dan mempunyai wilayah kekuasaan yang lebih besar dibandingkan Sukhotai. Kebudayaan Thailand dipengaruhi kuat oleh Tiongkok dan India. Hubungan dengan beberapa Negara besar Eropa dimulai pada abad ke-16. Meski mengalami tekanan yang kuat, Thailand tetap bertahan sebagai satu-satunya Negara di Asia Tenggara yang tidak 
pernah dijajah oleh Negara eropa. Namun demikian, pengaruh Barat termasuk ancaman kekerasan mengakibatkan berbagai perubahan pada abad ke-19 dan diberikannya banyak kelonggaran bagi pedagang-pedagang Britania.

Sebuah revolusi tak berdarah pada tahun 1932 menyebabkan perubahan bentuk Negara menjadi monarki konstitusional. Negara yang semula dikenal dengan nama Siam ini, mengganti namanya menjadi Thailand pada tahun 1939 dan untuk seterusnya, setelah pernah sekali mengganti kembali ke nama lamanya pasca Perang Dunia II. Pada perang tersebut, Thailand bersekutu dengan jepang, tetapi saat Perang Dunia II berakhir, Thailand menjadi sekutu Amerika Serikat. Beberapa kudeta terjadi dalam tahun-tahun setelah berakhirnya perang, namun Thailand mulai bergerak ke arah demokrasi sejak tahun 1980-an.

Negara Thailand mengambil bentuk monarki konstitusional dengan sistem demokrasi parlementer, dimana kekuasaan dan wewenang raja bersifat terbatas. Sedangkan urusan pemerintahan Negara dijalankan oleh perdana mentri, yang dilantik sang raja dari anggota-anggota parlemen dan biasanya adalah pemimpin partai mayoritas. Parlemen Thailand yang bikameral dinamakan Majelis Nasional atau Rathasapha, yang terdiri dari Dewan Perwakilan (Sapha Phuthaen Radsadon) yang beranggotakan 500 orang dan senat (Wuthissapha) yang beranggotakan 200 orang. Anggota keduanya dipilih melalui pemilu rakyat. Anggota Dewan Perwakilan menjalani masa bakti selama 4 tahun, sementara para senator menjalani masa bakti selama 6 tahun.

Populasi Thailand didominasi ethnis Thai dan Lao, yang berjumlah $3 / 4$ dari seluruh penduduk. Selain itu juga terdapat komunitas besar etnis Tionghoa yang secara historis memegang peranan yang besar dalam bidang ekonomi. Etnis lainnya termasuk etnis melayu di selatan, Mon. Khmer dan berbagai suku orang bukit. Sekitar 95\% penduduk Thailand adalah pemeluk agama budha aliran Theravada. Ada minoritas pemeluk agama Islam, Kristen, dan hindu. Bahasa Thailand merupakan bahasa nasional Thailand, yang ditulis menggunakan aksaranya sendiri tetapi ada banyak juga bahasa daerah lainnya, termasuk bahasa melayu. Bahasa inggris juga diajarkan secara luas di sekolah.

Dalam aspek ekonomi, Thailand pernah menikmati rata-rata pertumbuhan tertinggi di dunia dari tahun 1985 -1995, yaitu rata-rata 9\% pertahun. Tekanan spekulatif yang meningkat terhadap uang Thailand, Bath, pada tahun 1997 menyebabkan terjadinya krisis yang berdampak pada melemahnya sektor keuangan dan memaksa pemerintah untuk mengembangkan Bath. Setelah sekian lama dipatok pada nilai 25 Bath untuk satu dolar AS, Bath mencapai titik terendahnya pada kisaran 56 Bath pada januari 1998 dan ekonomi melemah sebesar 10,2\% pada tahun yang sama. Krisis ini kemudian meluas ke krisis financial Asia.

Ekonomi Thailand mengalami pemulihan dari krisis pada tahun 1999; menguat 4,2\% dan tumbuh 4,4\% pada tahun 2000. Pertumbuhan ini, sebagian besar merupakan hasil dari ekspor yang kuat yang meningkat sekitar $20 \%$ pada tahun yang sama. Pertumbuhan sempat diperlambat ekonomi dunia yang melunak pada tahun 2001, namun kembali menguat pada tahun-tahun berikut berkat pertumbuhan yang kuat di RRT dan beberapa program stimulant dalam negeri serta kebijakan dua jalur yang ditempuh pemerintah Thaksin Shinawatra. Pertumbuhan pada tahun 2003 mencapai $6,3 \%$ dan $8 \%$ dan $10 \%$ pada tahun 2004 dan 2005. Sektor pariwisata banyak memberikan sumbangan pada ekonomi Thailand. Kedatangan wisatawan tahun 2002 (10,9 jt) mencerminkan kenaikan sebesar 7,3\% dari tahun sebelumnya $(10,1 \mathrm{jt})$. 


\section{Sejarah Masuknya Islam di Thailand}

Kerajaan Thai yang lebih sering disebut Thailand dalam bahasa Inggris, atau dalam bahasa aslinya Mueang Thai (dibaca: "meng-thai", sama dengan versi Inggrisnya, berarti "Negeri Thai"), adalah sebuah negara di Asia Tenggara yang berbatasan dengan Laos dan Kamboja di timur, Malaysia dan Teluk Siam di selatan, dan Myanmar dan Laut Andaman di barat. Kerajaan Thai dahulu dikenal sebagai Siam sampai tanggal 11 Mei 1949. Kata "Thai" berarti "kebebasan" dalam bahasa Thai, namun juga dapat merujuk kepada suku Thai, sehingga menyebabkan nama Siam masih digunakan di kalangan warga negara Thai terutama kaum minoritas Tionghoa.

Muslim di Thailand sekitar 15 persen, dibandingkan penganut Budha, sekitar 80 persen. Mayoritas Muslim tinggal di Selatan Thailand, sekitar 1,5 juta jiwa, atau 80 persen dari total penduduk, khususnya di Pattani, Yala dan Narathiwat, tiga provinsi yang sangat mewarnai dinamika di Thailand Selatan. Thailand Selatan terdiri dari lima provinsi: Pattani, Yala, Narathiwat, Satun dan Songkhla, dengan total penduduk 6.326.732 (Kantor Statistik Nasional, Thailand, 2002).

Mayoritas penduduk Muslim terdapat di empat provinsi: Pattani, Yala, Narathiwat dan Satun, yaitu sekitar $71 \%$ diperkotaan, dan $86 \%$ di pedesaan sedangkan di Songkhla, Muslim sekitar $19 \%$, minoritas, dan $76.6 \%$ Buddha. Sementara mayoritas penduduk yang berbahasa Melayu, ratarata 70 persen berada di tiga provinsi: Pattani, Yala dan Narathiwat, sementara penduduk berbahasa China, ada di tiga provinsi: Narathiwat, 0.3 $\%$, Pattani, $1.0 \%$, dan Yala, $3.0 \%$ (Sensus Penduduk, Thailand, 2000).

Ada beberapa teori tentang masuknya Islam di Thailand. Diantaranya ada yang mengatakan Islam masuk ke Thailand pada abad ke-10 melalui para pedagang dari Arab. Ada pula yang mengatakan Islam masuk ke Thailand melalui Kerajaan Samudra Pasai di Aceh. Jika melihat peta Thailand, akan mendapatkan daerah-daerah yang berpenduduk muslim berada persis di sebelah Negara-negara melayu, khususnya Malaysia.

Hal ini sangat berkaitan erat dengan sejarah masuknya Islam di Thailand, "jika dikatakan masuk". Karena kenyataanya dalam sejarah, Islam bukan masuk Thailand, tapi lebih dulu ada sebelum Kerajaan Thailand "Thai Kingdom" berdiri pada abad ke-9. Islam berada di daerah yang sekarang menjadi bagian Thailand Selatan sejak awal mula penyebaran Islam dari jazirah Arab.

Hal ini bisa dilihat dari fakta sejarah, seperti lukisan kuno yang menggambarkan bangsa Arab di Ayuthaya, sebuah daerah di Thailand dan juga keberhasilan bangsa Arab dalam mendirikan Daulah Islamiyah Pattani menjadi bukti bahwa Islam sudah ada lebih dulu sebelum Kerajaan Thai. Lebih dari itu, penyebaran Islam di kawasan Asia Tenggara merupakan suatu kesatuan dakwah Islam dari Arab, masa khilafah Umar Bin Khatab" (teori arab). Entah daerah mana yang lebih dahulu didatangi oleh utusan dakwah dari Arab. Akan tetapi secara historis, Islam sudah menyebar di beberapa kawasan Asia Tenggara sejak lama, di Malakka, Aceh (Nusantara), serta Malayan Peninsula termasuk daerah melayu yang berada di daerah Siam (Thailand).

Pada tahun 1613, d'Eredia memperkirakan bahwa Patani masuk Islam sebelum Malaka yang secara tradisional dikenal sebagai "darussalaam (tempat damai) pertama" dikawasan itu (mills 1930:49). Dalam penelitiannya mengenai kedatangan Islam di Indonesia G.W.J Drewes menemukan bahwa di Trengganu, yang merupakan salah satu tetangga Patani, agama baru itu sudah dianut secara mapan menjelang 1386 atau 1387. 
Dari penemuan ini Wyatt dan Teeuw menarik kesimpulan bahwa tidak ada alasan mengapa (agama itu) belum sampai di Patani menjelang tahun itu terutama jika diingat bahwa Patani terkenal sebagai sebuah pusat Islam yang awal. Pada puncak kekuasaan patani awal abad ke 17 diletakkan dasar-dasar bagi perkembangan ilmu pengetahuan Islam. Ini dimungkinkan oleh hubungan yang semakin intensif antara negeri Arab yang merupakan pusat Islam dan Asia Tenggara yang ketika itu pusat perdagangannya.Masa kejayaan yang sudah lampau itu dilambangkan oleh kaum bangsawan dan hubungan kekerabatan mereka dengan keluarga Melayu dan oleh citra Patani sebagai "tempat kelahiran Islam" dikawasan itu.

Lembaga keagamaan di Patani dan daerah sekitarnya berfungsi sebagai penghubung antara golongan elit dengan rakyat. Kaum ulama berfungsi sebagai kekuatan yang mengabsahkan kekuasaan yang berlaku dan dukungan mereka sifatnya menentukan bagi pemelihara daan pengguna kekuasaan politik.

Pada tahun 2004 bertepatan pada bulan April, pada masa kepekimpinan Thaksin Shinawarta, insiden berdarah telah terjadi sehingga mengakibatkan 30 pemuda muslim tewas di masjid Kru Se. peristiwa keji terjadi yang kedua kalinya pada bulan oktober 2004 yang mengakibatkan 175 tahanan pejuang Muslim Takbai meninggal dunia, akibat dijejalkan militer Thailand dalam sebuah truk dengan kondisi tangan di belakang.

Pada perkembangan Muslim Pattani antara 2004 hingga Mei 2007. Periode ini sangat urgen tidak hanya karena banyaknya korban dalam kurun waktu ini, setidaknya 2000 korban meninggal. Sehingga di penghujung tahun 2008, Thailand ingin memiliki Perdana Menteri baru yang diharapkan dapat membawa angin perubahan. Dengan rezim barunya harus berjuang keras mencari alternative dalam menangani masalah konflik Thailand Selatan.

Rupanya perdamaian Aceh (Gerakan Aceh Merdeka) menjadi model upaya perdamaian dan rekonsiliasi di Thailand Selatan. Identitas lokal di Thailand Selatan lebih dekat dengan Kelantan dan Kedah, Malaysia. Masyarakat secara tradisional lebih memilih menggunakan bahasa Melayu dibandingkan bahasa Thai yang digalakkan oleh pemerintah pusat sebagai bahasa resmi negara. Keterpaksaan ini dirasakan masyarakat Melayu Muslim di Thailand Selatan selama puluhan tahun.

Penggunakan bahasa Thai diwajibkan oleh pemerintah, baik itu di kantor kerajaan, pemerintah, sekolah dan media. Dan ternyata strategi pemerintah Thailand memang membuahkan hasil. Dalam waktu sekitar 50 tahun, banyak generasi muda Melayu Muslim lebih suka berbahasa Thai dibandingkan bahasa Melayu, baik di sekolah maupun dalam pergaulan sehari-hari. Tetapi mereka 'dipaksa' keluarga untuk berbicara dalam bahasa Melayu ketika mereka berkumpul dilingkungan keluarga.

\section{Kehidupan Keberagamaan}

Ummat Islam di Thailand tidak seberuntung seperti Ummat Islam di Malaysia yang mana hampir semua sarana da'wah seperti masjid-masjid disediakan oleh pemerintah Malaysia. Demikian pula dengan Imam, Khotib, Bilal, dan penguruspengurus masjid digaji langsung oleh pemerintah. Sarana media seperti TV maupun radio di Malaysia diberikan waktu tiap malam untuk da'wah Islam.

Kawasan Thailand bagian selatan yang merupakan basis masyarakat melayumuslim adalah daerah konflik agama dan persengketaan wilayah dengan latar belakang ras dan agama yang berkepanjangan. Konflik Thailand selatan terjadi sejak diserahkannya wilayah utara Melayu oleh pemerintah colonial Inggris kepada kerajaan Siam. Saat itu dibuatlah Traktat Anglo-Siam yang menabut hak-hak dan martabat 
Muslim Pattani. Akibatnya, muncul aksi-aksi perlawanan dan ditanggap pemerintah pusat sebagai separatisme, hingga diberlakukan darurat militer di wilayah tersebut.

Di beberapa kota pelabuhan, Islam bukanlah agama bagi komunitas perkampungan melainkan agama para individu yang mobil yang menyatu dalam jaringan asosiasi internasional. Dari Singapura pembaharuan Islam menyebar ke seluruh Asia Tenggara melalui perdagangan, haji, dan melalui gerakan pelajar, guru dan sufi.

Sudah pada tempatnya dunia Islam segera meyampaikan appeal kepada pemerintah supaya elindng, menyelamatkan Ummat Islam dan memberikan persamaan hak di segala bidang kepada mereka, termasuk hak-hak untuk beribadah dan melaksanakan ajaran-ajaran Islam, hak yang sama dengan hak-hak yang dmiliki penduduk yang beragama Budha

\section{Perkembangan Islalm di Thailand Pendidikan}

Pendidikan yang digalakkan oleh pemerintah Kerajaan Thailand tergolong bersifat deskriminatif terhadap Islam. Pada tahun 1923 M, beberapa Madrasah Islam yang dianggap ekstrim ditutup, dalam sekolah-sekolah Islam harus diajarkan pendidikan kebangsaan dan pendidikan etika bangsa yang diambil dari inti sari ajaran Budha.

Pada saat-saat tertentu anak-anak sekolah pun harus menyanyikan lagu-lagu bernafaskan Budha dan kepada guru harus menyembah dengan sembah Budha. Kementrian pendidikan memutar balik sejarah, dikatakannya bahwa orang Islam itulah yang jahat ingin menentang pemerintahan shah di Siam dan menjatuhkan raja. Dampak yang menonjol dari perkembangan yang berorientasi ke dalam hal ini. Misalnya, pada tahun 1966, sekitar 60\% anak-anak di Pattani tidak dapat berbicara bahasa nasional. Hal itu berkaitan dengan banyaknya orang tua Muslim yang lebih senang mengirimkan anak-anaknya ke sekolah agama.

Strategi yang perlu dibangun masyarakat muslim di Thailand Selatan pada saat ini adalah memajukan pendidikan, mendukung pembangunan nasional, dan menjaga stabilitas local. Namun, sampai saat inipun masyarakat muslim Pattani Thailand menghadapi diskriminasi komplek dan teror yang berlarut-larut. Sehingga kehidupan sosial maupun politik menjadi sangat terbatas. Akhirnya pemerintah Thailand juga belum mampu memberi pendidikan merata terhadap kaum muslim. Tekanan berbasis keamanan selalu mengancam mereka. Kesenjangan ini menurunkan nasionalisme mesyarakat di luar mayoritas Thai-Budha.

\section{Kehidupan Muslim Thailand Sebagai Minoritas}

Perlulah kita membatasi definisi atau pengertian tentang minoritas muslim, karena terdapat sejumlah pertimbangan dalam masalah ini, dengan pengertian bahwa Negara yang jumlah penduduk kaum musliminnya lebih dari setengah jumlah penduduk, itu tergolong Negara Islam. Akan tetapi apabila jumlah kaum musliminnya kurang dari setengah jumlah penduduk, maka digolongkan (minoritas) masuk ke dalam Negara yang bukan Islam.

Negara bukan Islam yang berjulukan Negara Gajah Putih, tercatat minoritas kaum Muslim yang berjumlah sekitar 5\% atau 1,5 juta jiwa dari penduduk Thailand, Mayoritas Muslim tinggal di wilayah selatan khususnya Pattani, Yala, dan marathiwat. Mereka kerap terdiskriminasi dalam segala sektor kehidupan. Pada saat ini mayoritas penduduk Thailand yang beragama Budha sekitar $80 \%$. Daerah-dareh tersebut awalnya 
merupakan bagian dari sebuah kerajaan Melayu Islam Pattani Darusalam.Daerah yang sekarang disebut Thailand selatan pada masa dahulu berupa kesultanan-kesultanan yang merdeka dan berdaulat, diantara kesultanan yang terbesar adalah Patani. Thailand sebelumnya bernama Siam yang kemudian pada tahun 1939 M, Nama Siam diganti dengan Muangthai.

Derita yang dialami masyarakat muslim di Thailand Selatan yang sebagai minoritas ini adalah akibat dari pembatasan ruang gerak mereka untuk memperoleh hakhaknya dalam bidang ekonomi, politik, dan keagamaan. Juga karena problematika klasik yang telah berlangsung lama yang menyalahi keyakinan dan nilai-nilai keislamannya. Minoritas ini menuntut pemisahan diri dan kemerdekaan seperti yang telah dipaparkan sebelumnya, bahwa perdamaian Aceh (Gerakan Aceh Merdeka) menjadi model upaya perdamaian dan rekonsiliasi di Thailand Selatan.

Dalam tatanan sosial, muslimin Thailand mendapatkan julukan yang kurang enak untuk didengar. Yaitu Kheik atau khaek yang berarti orang luar, yang secara harfiah berarti pendatang atau orang yang datang menumpang. Dalam bahasa Thai, istilah ini juga selama berabad-abad sudah dikenal untuk menyebut kaum pendatang berkulit hitam dari daerah Melayu dan Asia Selatan, orang-orang Thai-Islam menolak sebutan ini dan menyatakan bahwa kedatangan mereka (khususnya di kawasan Thailand Selatan), jauh lebih awal daripada kedatangan orang-orang Budha Thailand.

Hingga istilah Thai-Islam dibuat pada 1940-an. Akan tetapi istilah ini menimblkan kontradiksi karena istilah Thai merupakan sinonim dari kata Budhasedangkan Islam identik dengan kaum muslim melayu pada waktu itu. Jadi bagaimana mungkin seseorang menjadi budha dan muslim pada satu waktu? Maka dari itu kaum muslim melayu lebih suka dipanggil Malay-Islam.

Dalam beberapa tahun terakhir, hubungan antar kerajaan Thai dengan masyarakat melayu-muslim tampak membaik. Putra mahkota kerajaan sering berkunjung ke propinsi-propinsi yang berbatasan dengan Malaysia itu. Pembangunan jalan dan gedung-gedung sekolah menandai adanya perhatian yang serius dari pihak kerajaan. Dan yang tak kalah pentingnya bagi melayu muslim adalah bahwa sejak tahu 1990-an mereka mulai mendapat kebebasan dalam menjalankan syari' at islam. Namun keinginan untuk memberlakukan hokum islam diwilayah mereka itu tetap terus mereka perjuangkan.

Hubungan pemerintah dan melayu-muslim yang mulai membaik ini tak dapat dipisahkan dari semakin segarnya angin demokrasi yang bertiup dinegara-negara sedang berkembang termasuk Thailand. Seperti dikemukakan Abdul Rozak, seorang tokoh patani, bahwa perubahan sikap pemerintah Thailand itu agaknya lebih karena tekanan internasional sehubungan dengan sedang menghangatnya isu

Hak Asasi Manusia (HAM). Akan tetapi, meski pemerintah mencoba memperbaiki hubungannya dengan melayu-muslim, mereka masih belum bisa menghilangkan trauma masa lalunya, terutama kalangan generasi tua. "kami masih ingat beberapa tahun yang lalu untuk pakai kopiah dan sarung saja tidak diperbolehkan. Sehari-hari pun kami diharuskan menggunakan bahasa thai", ujar seorang bapak di Narathifat mengenag pahitnya masa lalu. Kuatnya kesadaran akan masa lalu yang pahit, ditambah oleh kenyataan masih adanya "kaki tangan kerajaan yang menganggap umat islam di kawasan selatan Thai seperti api dalam sekam" membuat melayu-muslim ini tetap menjaga jarak dengan pemerintah Thailand. 
Hal ini antara lain terindikasi dari cara mereka yang menjaga kemandirian financial lembaga pendidikan tradisional pesantren. Dengan menolak menerima bantuan pemerintah mereka bisa terbebas dari sikap pemerintah untuk mendikte mereka.

Konflik di Thailand Selatan sangat kental dengan nilai-nilai gama. Mereka melihat konflik ini adalah pertarungan antara Muslim Melayu dan Buddis Thai. Kata 'Muslim' dan 'Buddhis' mengarahkan pada kuatnya pengaruh agama dalam masingmasing masyarakat. Apabila dilihat lebih dekat, identitas Muslim Melayu di Selatan memang sangat kuat. Masyarakat khususnya di tiga provinsi: Pattani, Yala, dan Narathiwat memiliki identitas keislaman dan keMelayuan yang tidak bisa dipisahkan. Masyarakat lebih welcome dengan orang Melayu dari pada dengan etnis lain, terutama Thai.

Penggunaan bahasa melayu menurut statistik nasional Thailand juga sangat kuat di tiga provinsi ini, di atas $70 \%$, dibandingkan provinsi lain di Selatan: Satun dan Songkhla. Tetapi bahasa melayu 'dilarang' digunakan sebagai bahasa resmi di perkantoran, lembaga pendidikan pemerintah, dan tempat atau acara resmi lainnya. Larangan ini tidak menyurutkan masyarakat untuk menggunakan bahasa Melayu, karenabahasa ini memberi spirit identitas mereka, yang berbeda dengan mayoritas warga Thailand, yang berbahasa Thai dan Buddha.

Dalam tiga tahun terakhir, lebih dari 200 orang meninggal berkaitan dengan konflik di Thailand Selatan. Korban lebih banyak ditembak dan dibom oleh kelompok yang tidak dikenal, juga oleh pendekatan militer dan polisi terhadap muslim. Pada April 2004, 30 pemuda Muslim ditembak oleh tentara di Masjid Krue Se. Masjid ini sangat bersejarah karena didirikan pada abad 15, masjid tertua di Thailand. Satu periode dengan masa kejayaan Islam pada Khalifah Abbasiyah.

Peristiwa kedua adalah pada Oktober 2004, sekitar 175 Muslim Takbai meninggal di perjalanan, setelah mereka demonstrasi kepada pemerintah dan dimasukkan dalam truk dalam kondisi terikat tangan di belakang. Dua peristiwa ini sangat membekas dihati Muslim, dan banyak pemuda dan masyarakat Muslim semakin meningkatkan penyerangan terhadap berbagai organ pemerintah maupun masyarakat Buddha. Reaksi Musli Selatan ini direspon negative oleh pemerintah, dengan tetap memberlakukan darurat militer di kelima provinsi ini.

Peristiwa Takbai yang menewaskan Muslim sekitar 200 orang menimbulkan reaksi pa;ing keras dari milisi Muslim, yang kemudian membalas dengan penembakan dan pemboman misterius yang menargetkan korban tentara, polisi, pegawai pemerintah Thai, etnis China dan pendeta Buddha. Hampir setiap bulan sejak peristiwa 2004, terjadi korban dipihak tentara atau Buddha. Kerusuhan ini sempat menjadi perhatian Amerika Serikat yang menawarkan bantuan keamanan untuk mengatasi 'gerilyawan' dari Selatan.

Pada bulan Pebruari 2004, Organisasi Konferensi Islam (OKI) minta pemerintah Thailand untuk mengakhiri tindak kekerasan terhadap warga Muslim di wilayah selatan Thailand. Seruan ini menjadi salah satu point dalam pernyataan hasil pertemuan di Jeddah antara Sekretaris Jendral OKI Prof. Ekmeleddin Ihsanoglu dan Perdana Mnteri Malaysia Abdullah Badawi, yang mengetuai Konferensi Tingkat Tinggi Islam ke-10.

Prof. Ihsanoglu mengungkapkan rasa ketidakpuasannya, karena tindak kekerasan terhadap warga Muslim di Thailand masih terus terjadi meskipun OKI dan dunia internasional sudah mendesak pemerintah Thailand untuk segera mengakhirinya. Sekjen OKI itu kembali mengingatkan Thailand pentingnya menegakkan keadilan dan investigasi atas kasus-kasus kekerasan terhadap warga Muslim. Ihsanoglu juga 
menekankan agar pemerintah Thailand tidak bersikap diskriminasi dalam hal pembangunan ekonomi dan sosial di wilayah selatan Thailand yang mayoritas penduduknya beragama Islam.

Upaya rekonsiliasi telah dilakukan oleh pemerintah pusat dalam lima tahun terakhir, dengan terbentuknya Komisi Rekonsiliasi Nasional yang mengantarkan dan memediasi perdamaian di Selatan. Kuatnya peran tentara di Thailand, membuat banyak rekomendasi komisi tidak bisa dijalankan. Pendidikan, pekerjaan dan fasilitas pemerintah lainnya tetap saja tidak leluasa dinikmati bagi Muslim Melayu. Persyaratan pemakaian ketat bahasa nasional Thai dan sikap yang mencerminkan nasionalisme pro kebijakan pusat menjadi penghambat rekonsiliasi yang telah dilakukan baik oleh lembaga swadaya masyarakat, perguruan tinggi, dan komisi rekonsiliasi. Kehadiran masyarakat inetrnasional, antara lain Nahdlatul Ulama yang menjembatani ulama di Thailand Selatan dan pemerintah kerajaan Thailand akan banyak membuahkan hasil jika pemerintah pusat mengakomodasi gagasan dan harapan Muslim Melayu di Selatan, yaitu penggunaan tradisi Muslim Melayu lebih terbuka, dan pengakuan pemerintah pusat atas tradisi ini, khususnya di Pattani, Yala, dan Narathiwat.

Sementara itu, Partai Demokrat yang menekankan persatuan kuat Negara Thailand tidak berbuat banyak dalam perdamaian di Selatan, khususnya mendukung kepentingan Muslim. Kritik ini tentu penting diperhatikan oleh pihak politisi, yang memainkan isu Selatan untuk kepentingan mereka. Partai Thai Rak Thai yang dalam periode Thaksin memenangi parlemen secara sengaja meniunggalkan Selatan dalam proses pembangunan dan modernisasi Thailand secara umum. Bahkan membiarkan kerusuhan di Selatan. Sejak tahun 2004, kekerasan di Thailand Selatan yang mayoritas penduduknya beragama Islam telah menewaskan 2.200 orang. Kerusuhan yang muncul di pelihara oleh kelompok tertentu yang memiliki kepentingan. Di antara mereka adalah aparat pemerintah.

Dengan demikian, dapat disimpulkan, tumbuhnya sikap anti pemerintah pusat yang dilakukan oleh Muslim di Selatan Thailand diakibatkan banyak hal. Kesenjangan ekonomi menjadi kunci atas terus berlangsungnya gerakan 'separatisme' atau dalam istilah David Brown sebagai 'separatime etnis' atas dominasi kolonialisme internal Thailand. Kesenjangan ini telah berlangsung puluhan tahun. Akibatnya, masyarakat muslim yang mendapat tekanan politis dan keamanan dari pemerintah tidak bisa berbuat banyak. Sebagian dari mereka secara diam-diam mendukung gerakan anti pemerintah. Bahkan beberapa diantara mereka aktif terlibat dalam aksi kekerasan.

Dakwah Islam senantiasa di seluruh penjuru dunia. Islam adalah agama yang tidak mengenal batas dan sekat-sekat nasionalisme. Pun di sebuah negeri yang mayoritas penduduknya bukanlah pemeluk agama Islam Thailand.

Thailand dikenal sebagai negara yang pandai menjual potensi pariwisata sekaligus sebagai salah satau negara agraris yang cukup maju di Asia Tenggara. Mayoritas penduduk Thailand adalah bangsa Siam, Tionghoa dan sebagian kecil bangsa Melayu. Jumlah kaum muslim di Thailand memang tidak lebih dari 10\% dari total 65 juta penduduk, namun Islam menjadi agama mayoritas kedua setelah Budha.

Penduduk muslim Thailand sebagian besar berdomisili di bagian selatan Thailand, seperti di propinsi Pha Nga, Songkhla, Narathiwat dan sekitarnya yang dalam sejarahnya adalah bagian dari Daulah Islamiyyah Pattani. Kultur melayu sangat terasa di daerah selatan Thailand, khususnya daerah teluk Andaman dan beberapa daerah yang berbatasan langsung dengan Malaysia. Bahkan beberapa nama daerag berasal dari 
bahasa Melayu, seperti Phuket yang berasal dari kata bukit dan Trang yang berasal dari kata terang.

Proses masuknya Islam di Thailand dimulai sejak kerajaan Siam mengakuisi kerajaan Pattani Raya (atau lebih dikenal oleh penduduk muslim Thai sebagai Pattani Darussalam). Pattani berasal dari kata al-Fattani yang berarti kebijaksanaan atau cerdik karena di tempat itulah banyak lahir ulama dan cendekiawan muslim terkenal. Berbagai golongan masyarakat dari tanah Jawa banyak pula yang menjadi pengajar al-Qur'an dan kitab-kitab Islam berbahasa Arab Jawi. Beberapa kitab Arab Jawi sampai saat ini masih diajarkan di beberapa sekolah muslim dan pesantren di Thailand Selatan.

Perkembangan Islam di Thailand semakin pesat saat beberapa pekerja muslim dari Malaysia dan Indonesia masuk ke Thailand pada akhir abad ke-19. Saat itu mereka membantu kerajaan Thailand membangun beberapa kanal dan system perairan di Krung Theyp Mahanakhon (sekarang dikenal sebagai Propinsi Bangkok).

Beberapa keluarga muslim bahkan mampu menggalang dana dan mendirikan masjid sebagai saran ibadah, sebuah masjid yang didirikan pada tahun 1949 oleh warga Indonesia dan komunitas muslim asli Thailand. Tanah wakaf masjid ini adalah milik Almarhum H. Saleh, seorang warga Indonesia yang bekerja di Bangkok.

Masjid Jawa adalah masjid lain yang juga didirikan oleh komunitas warga muslim Indonesia di Thailand. Sesuai dengan namanya, pendiri masjid ini adalah warga Indonesia suku Jawa yang bekerja di Thailand. Namun demikian, anak cucu para pendiri masjid ini berbicara dalam bahasa Thai dan Inggris saat menceritakan asal muasal berdirinya Masjid Jawa ini. Masjid Indonesia dan Masjid Jawa hanyalah sebagian dari lima puluhan masjid lain yang tersebar di seluruh penjuru Bangkok.

\section{Lembaga-Lembaga Islam di Thailand}

Thailand merupakan Negara yang penduduknya minoritas muslim karena mayoritas penduduk disana beragama budha. Meskipun penduduk muslimnya minoritas tetapi di Thailand memiliki lembaga atau kelompok yang kuat dan aktif. Empat kelompok gerakan Islam yang kuat dan aktif : pertama, golongan tradisional yang sangat berpengaruh di selatan. Kedua, golongan ortodoks yang menerbitkan majalah Rabbitah. Ketiga, golongan modernis yang menerbitkan jurnal al-Jihad. Keempat, golongan Chularajamontri 66 yang disponsori oleh pemerintah. Terdapat beberapa kelompok gerakan.

Adapun kelompok-kelompok yang beragam dari organisasi separatis mengaku beroperasi dipropinsi-propinsi melayu, Muangthai selatan. Kelompok tertua adalah Barisan Nasional Pembebas Patani (BNPP) yang didirikan oleh seorang aristrokat Melayu. Barisan ini adalah kelompok Islam konservatif dan dipercaya punya hubungan yang dekat dengan Partai Islam se Malaysia (PAS) yang berkuasa di Negara tetangga Kelantan.

Secara ideologis bertentangan dengan BNPP, Barisan Revolusi Nasional (BRN) yang didirikan oleh seorang guru agama, punya suatu sikap yang didasarkan pada ajaran kiri. Karena diduga beraliansi dengan Partai Komunis Malaysia (CPM), BRN Nampak kurang menerima dukungan dari rakyaat. Kelompok sabilillah ( jalan Allah) adalah kelompok berbasis kota yang muncul selama demonstrasi besar yang dilakukan Patani di akhir tahun 1975 dan awal 1976.

Kelompok yang paling sedikit dikenal adalah Desember Hitam 1902 yang identitasnya diambil dari peristiwa sejarah penytuan Patani Raya kedalam kerajaaan 
Thai. Kelompok yang paling terkenal adalah Patani United Liberation Organization (PULO) didirikan seorang aristocrat dan memiliki tujuan menyatukan semua faksi-faksi politik yang aktif melawan imperialisme Thai nampak ditujukan pada semua masyarakat melayu

\section{Kesimpulan}

Thailand merupakan salah satu Negara di wilayah di Asia Tenggara yang mayoritas penduduknya beragama Budha. Tetapi didalam Thailan terdapad provinsi yang mayoritas penduduknya beragama Islam yaitu di Thailand Selatan. Tepatnya di Pattani dan beberapa provinsi lainnya.

Islam masuk di Thailand dengan cara perdagangan oleh orang-orang Arab. Buktinya lukisan kuno yang menggambarkan bangsa Arab di Ayuthaya, sebuah daerah di Thailand dan juga keberhasilan bangsa Arab dalam mendirikan Daulah Islamiyah. Meskipun Islam merupakan agama yang minoritaas di Thailand tetapi Islam mempunyai lembaga yang berpengaruh di Thailand yaitu Patani United Liberation Organization (PULO).

\section{Referensi}

Al-Aydrus Muhammad Hasan. Penyebaran Islam di Asia Tenggara. Jakarta: Lentera, 1996.

Artikel Sejarah Masuknya Islam di Philipina oleh Imam nugroho di www.duiniaislam.com.

Saiful Muzani. Pembangunan dan Kebangkitan Islam di Asia Tenggara. Jakarta: LP3ES, 1993.

Kettani M Ali, Minoritas Muslim di dewasa ini, Jakarta: PT Raja Grafindo Persada: 2005.

Kettani M Ali, Minoritas Muslim di dewasa ini, Jakarta: PT Raja Grafindo Persada, 2005.

Surin Pitssuwan. Islam Di Muangthai, Jakarta: LP3ES, 1989.

Supriyadi Dedi. Sejarah Peradaban Islam. Bandung: CV Pustaka Setia, 2008. 